\title{
Influence of the benthos on growth of planktonic estuarine bacteria
}

\author{
Charles S. Hopkinson $\mathrm{Jr}^{1,{ }^{*}}$, Anne E. Giblin ${ }^{1}$, Robert H. Garritt ${ }^{1}$, Jane Tucker ${ }^{1}$, \\ Meredith A. J. Hullar ${ }^{2}$
}

${ }^{1}$ The Ecosystems Center, Marine Biological Laboratory, Woods Hole, Massachusetts 02543, USA

${ }^{2}$ Organismic and Evolutionary Biology, Harvard University, Cambridge, Massachusetts 02138, USA

\begin{abstract}
Estuarine planktonic bacteria were incubated (bacterial bioassays) in water previously held in close contact with benthic sediments to assess the potential importance of benthic dissolved organic matter for planktonic bacterial production. The study was conducted using water and sediments collected from along a fresh to salt water gradient in the Parker River and Plum Island Sound Estuary in northern Massachusetts, USA. Initial concentrations of dissolved inorganic nutrients were elevated relative to ambient estuarine water while initial concentrations of dissolved organic carbon were higher during a June bioassay and lower during a December bioassay relative to ambient water. Specific growth rates of planktonic bacteria were calculated from changes in cell numbers during the exponential growth phase. Growth rates were very high, ranging from about 3.6 to $6.5 \mathrm{~d}^{-1}$. Rates at individual sites were generally higher in June than in December and higher in low salinity waters than in high salinity waters. These rates are substantially higher than bacterial growth rates typically found in the water column of Plum Island Sound ( 1.5 to $65 \times$, depending on method) but had the same spatial pattern as is commonly found in the estuary. Growth rates were comparable to those observed during experimental additions of marsh macrophyte leachate to incubations. Growth rates were linearly related to initial dissolved organic carbon (DOC) concentration in the bioassays, suggesting that substrate may limit bacterial growth. Stable isotopic compositions $\left(\delta^{13} \mathrm{C}\right.$ and $\left.\delta^{15} \mathrm{~N}\right)$ of microbes grown in the bioassay indicated utilization of benthic derived DOC even during times when the net flux of DOC was from overlying water into sediments. Further, the $\delta^{15} \mathrm{~N}$ of bioassay microbes suggested that microbes utilized benthic derived inorganic $\mathrm{N}$ to supplement an organic diet deficient in organic nitrogen. It appears that growth rates were elevated as a result of dissolved organic matter exchange with bottom sediments. These results suggest that there were gross fluxes of organic matter across the sedimentwater interface that were not apparent from net changes in DOC concentration in the overlying water pool. This study indicates that benthic systems must be seen not only as sites of inorganic nutrient remineralization important in support of planktonic primary producers, but also as sites of dissolved organic matter generation and nutrient remineralization important in support of bacterioplankton production.
\end{abstract}

KEY WORDS: Bacteria $\cdot$ Bacterial growth $\cdot$ Dissolved organic matter $\cdot$ DOC $\cdot$ DON $\cdot$ Estuarine sediments

\section{INTRODUCTION}

Estuaries are among the most productive ecosystems in the biosphere; they support high rates of secondary production, including commercially important fisheries. Estuaries are also characterized as detrital systems where a large majority of organic matter is processed by microbial organisms. High microbial growth rates are

·E-mail: chopkins@lupine.mbl.edu attributed in part to the variety and magnitude of organic matter inputs including rivers, the ocean, marshes, benthic algae and phytoplankton. An additional possibly important source of organic matter to estuarine microbes that has received little investigation to date is dissolved organic matter (DOM) from sediments. While not a new source in the sense of allochthonous terrestrial inputs of $\mathrm{C}$, sediments may be an important site of dissolved organic carbon (DOC) production from decomposing particulate organic matter of local or external origin. 
The benthos is an especially important component of generally shallow estuarine ecosystems because relatively large fractions of organic matter inputs settle to the bottom and are processed there. Sedimentation of particulate matter and flocculation of DOM insure that a great percentage of allochthonous organic matter inputs to estuaries is processed by the benthos (Smith \& Hollibaugh 1993). In general, 25 to $50 \%$ of total organic matter decomposition in estuaries occurs in the benthos (Nixon 1981).

Concentrations of dissolved organic carbon and nitrogen (DOC and DON) in surficial sediments are often an order of magnitude higher than those in the overlying water, leading to the conclusion that DOC and DON are produced in sediments during the decomposition of organic matter and exchanged between sediments and the overlying water (Burdige \& Homstead 1994). Numerous authors have discussed the possible importance of benthic DOC fluxes in sedimentary and oceanic C cycling (Emerson \& Dymond 1984, Williams \& Druffel 1987, Burdige \& Homstead 1994, Martin \& McCorkle 1994). Burdige et al. (1992) estimated that the global benthic flux of DOC was comparable in magnitude to riverine inputs of organic $\mathrm{C}$, benthic remineralization of $\mathrm{C}$ or organic $\mathrm{C}$ burial. However, the role of sediments as a source of DOC to the planktonic systems as well as the production of DOC in sediments is still poorly understood.

In the few places where fluxes have been monitored directly via bell jar or core incubation techniques, the evidence for fluxes of the magnitude predicted by diffusional considerations has been equivocal (Hartwig 1976, Boynton et al. 1980, Nixon et al. 1980, Burdige \& Homstead 1994). Seasonal studies in coastal Georgia revealed that the flux of DOM is not unidirectional but varies over time (Hopkinson 1987). In Plum Island Sound (Massachusetts, USA), we observed periods of uptake or release of DOC and DON over an annual cycle throughout the estuary (Hopkinson et al. in press)

Discrepancies between fluxes estimated from porewater gradients and those measured directly are likely the result of a dyramic balance between DOM production and DOM consumption by an active microbial community at the sediment-water interface. When microbial demand in surface sediments exceeds the supply of DOM, periods of benthic DOM consumption may result, i.e. DOM fluxes into the sediment. High rates of DOM utilization by the surface microbial community suggest that the lability of the DOM produced in sediments is high. Hopkinson et al. (1997) observed rapid microbial decomposition of DOC collected from water overlying a core of sediment from the Middle Atlantic Bight. Important questions that arise then are: What effect does DOM from benthic sediments have on planktonic microbes? Does the 'benthic effect' vary over time and space in an estuary? Does sediment DOM augment the production of planktonic microbes? What are the primary sources of organic matter to the sediments that are potentially stimulating growth of planktonic microbes?

In this paper we report the results of a bacterial bioassay study to investigate the potential effects of the benthos on productivity of planktonic bacteria. The study was conducted at several locations along the length of an estuary during periods of benthic DOC influx and efflux. Rates of bacterial growth following exposure to the benthos are compared to rates for open water estuarine bacteria. Also reported are stable carbon and nitrogen isotopic ratios of bacteria grown following exposure to bottom sediments and their likely sources of organic matter and inorganic nitrogen.

\section{MATERIALS AND METHODS}

Study area. The study was conducted in Plum Island Sound Estuary and the Parker River in northeastern Massachusetts, USA. The $155 \mathrm{~km}^{2}$ Parker River watershed is largely undisturbed, with extensive upland, bottomland hardwood and cedar swamp forests. Runoff from the watershed averages $2.7 \mathrm{~m}^{3} \mathrm{~s}^{-1}$ and is markedly seasonal. Nutrient levels in the Parker River are low to moderate (Hopkinson \& Finn unpubl.), with total dissolved nitrogen (TDN) annually averaging about $39 \mu \mathrm{M}$, with organic nitrogen comprising about $53 \%$ of the total. Organic $C$ inputs are dominated by the dissolved fraction $(90 \%)$, with concentrations annually averaging about $480 \mu \mathrm{M}$.

The Plum Island Sound Estuary is a productive, riverine, macrotidal marsh system with vegetation typical of New England marshes. The upper half of the estuary $(0$ to $15 \mathrm{~km})$ is a tidal river with wetland area exceeding water area by about $5: 1$. The lower half $(15$ to $25 \mathrm{~km}$ ) is a broad shallow sound with roughly equal areas of wetland and water. Major wetland species are Spartina alterniflora and $S$. patens in brackish and saline regions and Typha, Scirpus and Carex in fresh water regions

Planktonic bacterial numbers and production exhibit regular temporal and spatial patterns (Wright \& Coffin $1983,1984 \mathrm{a})$. In winter, counts and activity are uniformly low throughout the estuary, while during spring, summer and fall there are peaks of bacteria and activity in mid-estuarine waters. It has been suggested for this system that grazing largely controls bacterial numbers while substrate supply is the primary control on production (Wright et al. 1987).

Benthic metabolism and nutrient fluxes vary widely along the length of the estuary (Hopkinson et al. in 
Table 1. Range or average annual conditions of the benthos at 4 stations in the Plum Island Sound Estuary and Parker River (Hopkinson et al. in press). Station letter designations refer to location either within the Parker River (PR) or the Estuary (E) while numbers refer to distance from a dam at the head of the estuary $(0 \mathrm{~km})$

\begin{tabular}{|lcccrc|}
\hline Stn & $\begin{array}{c}\text { Salinity } \\
(\%)\end{array}$ & $\begin{array}{c}\text { Organic C } \\
(\% \text { dry wt })\end{array}$ & $\begin{array}{c}\text { Respiration } \\
\left(\mathrm{mmol} \mathrm{C} \mathrm{m}^{-2} \mathrm{~d} \mathrm{~d}^{-1}\right)\end{array}$ & $\begin{array}{c}\text { DIN flux } \\
\left(\mathrm{mmol} \mathrm{N} \mathrm{m}^{-2} \mathrm{~d}^{-1}\right)\end{array}$ & $\begin{array}{c}\text { DOC flux } \\
\left(\mathrm{mmol} \mathrm{C} \mathrm{m}^{-2} \mathrm{~d}^{-1}\right\}\end{array}$ \\
\hline PR0 & 0 & 10.3 & 21 & 1.7 & 11.9 \\
E2 & $0-18$ & 4.4 & 33 & 4.8 & 9.7 \\
E10 & $0.5-29$ & 2.1 & 170 & 21.2 & -11.4 \\
E18 & $20-33$ & 0.2 & 24 & 0.1 & 0.2 \\
\hline
\end{tabular}

press). Average conditions over the course of a year are summarized in Table 1. At all stations, fluxes are lowest during winter and highest during summer. DOC fluxes vary over the course of a year from being positive (to the overlying water) to negative. The pattern of DON flux does not closely parallel that of DOC.

Primary production and chlorophyll and nutrient concentrations have distinct seasonal and spatial patterns in Plum Island Sound estuary. Nitrate is higher at the freshwater end $(\sim 15 \mu \mathrm{M})$ and lower at the marine end $(<1 \mu \mathrm{M})$, while $\mathrm{NH}_{4}{ }^{+}$is highest in the middle of the estuary $(<8 \mu \mathrm{M})$ (Vörösmarty \& Loder 1994). Primary productivity is highest in the upper reaches of the tidal river and is fairly uniform throughout the remainder of the estuary. During summer, chl a concentrations often exceed $40 \mu \mathrm{g}^{-1}$ in the upper estuary and during winter they are as high as $20 \mathrm{\mu g} \mathrm{l}^{-1}$ in the sound. In the lower estuary, chl a standing stocks in sediments exceed those in the water column by a factor of 25 averaged over the year (176 vs $7 \mathrm{mg} \mathrm{chl} \mathrm{a} \mathrm{m}^{-2}$ ). DOC concentrations are high $(800 \mu \mathrm{M})$ at the freshwater end and low $(100 \mu \mathrm{M})$ in the marine end of the estuary (Fry et al. 1991).

Stn PRO is located in a pond immediately upstream of a waterfall leading into the estuary. Sediments are soft, with large percentages of silt, clay and organic matter. Stns E2 and E10 are within the tidal river portion of the estuary, approximately 1.8 and $9.6 \mathrm{~km}$ downstream of the falls. Sediments are primarily silts and clays and sandier at the mid-salinity site than at the low salinity site. Stn E18 is located midway along Plum Island Sound (18.4 km downstream) and is a very dynamic region with sediments almost exclusively sand. Tidal currents extensively rework the easily eroded sands.

Experimental procedures. We used a bacterial bioassay procedure to evaluate the potential effect of water being in contact with the benthos on the growth of planktonic bacteria. Bioassay approaches have been used previously to assess bacterial growth and DOC dynamics (e.g. Ammerman et al. 1984, Kirchman et al. 1991, Zweifel et al. 1993). In brief, following a 1 to $2 \mathrm{~d}$ incubation of sediment cores (part of a benthic flux study - see Hopkinson et al. in press), the water over- lying the sediments was removed, filter sterilized, and inoculated with estuarine microbes and the time course of changes in bacterial numbers and sizes was monitored over about a 1 wk period. Bioassays were performed twice during the year: in June-when benthic metabolism and nutrient flux were high and DOM flux was positive, and again in December-when benthic metabolism and nutrient flux were low and DOM flux was negative. To assess the effect of sediment contact, rates were compared to similar bioassays $(0.2 \mu \mathrm{m}$ filtration, $0.6 \mu \mathrm{m}$ inoculum, and room temperature incubation) run on different dates using estuarine water not having prior intimate contact with bottom sediments.

Sediment core collection and incubation procedures for measuring benthic metabolism and nutrient flux were described previously (Hopkinson et al. in press). In short, $16 \mathrm{~cm}$ diameter cores were taken directly from sediments in the field, avoiding disruption of the surface floc layer. Cores were held at in situ temperature until commencing flux measurements within $24 \mathrm{~h}$. Cores were incubated at in situ temperature, following replacement of overlying water $(\sim 20 \mathrm{~cm})$, until $\mathrm{O}_{2}$ levels dropped to $40-50 \%$ of saturation levels ( 1 to $2 \mathrm{~d}$ ). The source of overlying water was from the water column at each benthic sampling station. At the time of collection, it was filtered through a $1.0 \mu \mathrm{m}$ cartridge filter and held at in situ temperature until use. Following the benthic incubation, the overlying water from replicate cores was pooled for each station, siphoned into separate containers and refrigerated overnight until further processing for the bioassay.

Overlying water samples were pressure filtered (very low pressure, $<20 \mathrm{kPa}$ ) in 2 stages: (1) with a $95 \mathrm{~mm}$ stainless steel filtration apparatus (acid washed and rinsed with deionised water [DI]) using precombusted and rinsed Whatman GF/F glass fiber filters and (2) with thoroughly prerinsed Whatman $0.2 \mu \mathrm{m}$ cartridge filters. Water was collected in a single, well leached, acid washed and DI rinsed polyethylene container. This entire procedure was developed and tested over a period of years; DOC contamination was not detectable. The filtered water was then inoculated with estuarine microbes $(20: 1$ dilution). Estuarine microbes 
were from separate water samples from the study sites that had been filtered through $0.6 \mu \mathrm{m}$ Nuclepore filters (acid soaked and DI rinsed). Inoculated water was then incubated in triplicate in $20 \mathrm{l}$ polyethylene containers (leached, acid washed and DI rinsed). $\mathrm{HgCl}_{2}$ was added to 1 of the 3 replicates to serve as a killed control.

Bioassays were incubated in the dark at room temperature $\left(-20^{\circ} \mathrm{C}\right)$ and stirred prior to sampling. As this was a first attempt at assessing the potential importance of benthic DOM, we were not concerned with running bioassays at in situ temperatures. Bacterial numbers and sizes were analyzed at several time points over about a $1 \mathrm{wk}$ period. Bacterial abundance was determined following the procedure of Porter and Feig (1980). We used color, image-analyzed fluorescence microscopy (Verity \& Sieracki 1993) with Axiophot instrumentation. Universal Imaging Corporation Image 1 image processing software included routines for background subtraction, image averaging, and contrast enhancement. Bacteria growth rates during the exponential growth phase were determined from the slope of the relation between natural logarithm (ln) transformed numbers and time.

At the final sampling time in December, microbial particles (live and dead bacteria and heterotrophic nanoflagellates) were collected and their stable isotopic composition measured to indicate the ultimate plant source of DOM supporting microbial growth in the bioassays. Particles were sampled on a $25 \mathrm{~mm}$ Whatman GF/F glass fiber filter (preashed and rinsed). Stable isotopic ratios $\left(\delta^{13} \mathrm{C}\right.$ and $\left.\delta^{15} N\right)$ of the particles were determined after drying and acid fuming on a Finnegan delta $S$ isotope ratio mass spectrometer. There was insufficient material in the killed control containers to perform stable isotopic analysis, even upon filtering the entire container.

Analysis methods for DOC, DON, and inorganic $\mathrm{N}$ and $P$ have been described previously (Giblin et al. 1997, Hopkinson et al. in press). Briefly, DOC was measured using a custom, high temperature catalytic $\mathrm{C}$ analyzer designed and built by Edward Peltzer at the Woods Hole Oceanographic Institution, Woods Hole, MA, USA. It employs a 2 -zoned furnace $\left(800^{\circ} \mathrm{C}\right.$ top, $600^{\circ} \mathrm{C}$ bottom) with $\mathrm{Pt}$ on alumina catalyst, $\mathrm{CuO}$ and Sulfix in the combustion zone, a dehumidification system, dual particle filters, a solid-state NDIR detector and a PC-based integration system. Accuracy is determined using a known, low $\mathrm{C}$ blank water and sucrose standards. The precision of analysis in our lab is generally in the 2 to $5 \%$ range. DON was determined as the difference between TDN and inorganic nitrogen. TDN was determined either by UV oxidation followed by $\mathrm{NO}_{3}{ }^{-}$analysis by Ted Walsh (University of Hawaiiprecision 3 to $5 \%$ ), or with an Antek TN analyzer $\left(1100^{\circ} \mathrm{C}\right.$ furnace and chemiluminescent detection of resultant $\mathrm{NO}_{x}$-precision 5 to $10 \%$ ). Inorganic nutrients were determined with standard techniques (Grasshoff et al. 1983): $\mathrm{NH}_{4}{ }^{+}-$phenol/hypochlorite; $\mathrm{NO}_{3}{ }^{-}-$ cadmium reduction and sulphanilamide $\mathrm{PO}_{4}{ }^{3-}$ ascorbic acid and heptamolybdate.

\section{RESULTS AND DISCUSSION}

\section{Initial conditions}

Relative to ambient concentrations in the water column of the Parker River and Plum Island Sound Estuary, initial concentrations in the bioassay water were slightly different for DOC and substantially higher for inorganic nitrogen. Deviations from ambient conditions reflect the dissolved material fluxes across the sediment-water interface that occurred during benthic flux measurements prior to conducting the bioassay experiments. Over the course of the year we have observed periods of DOM flux into and out of the sediments. In June, concentrations were uniformly higher following incubation (avg: $+16 \%$ ), while in December, concentrations were uniformly lower (avg: $-6 \%$ ). As the precision of our DOC analysis is about 2 to $4 \%$, only differences $\geq 4 \%$ were significant. These patterns indicate that the benthos was a net source of DOC to the planktonic community in the water column in June but a net sink in December.

Overall concentrations and spatial patterns of DOC at the outset of the bacterial bioassays were typical for this marsh and river-dominated estuary even following the benthic incubation (Peterson et al. 1994). Concentrations at each station were uniformly higher in December than during June (Table 2). During both times of the year, concentrations were highest in the low salinity region of the estuary (Stn E2) and lowest in the high salinity region (Stn E18). The $\mathrm{C} / \mathrm{N}$ ratios of DOM at the outset of the bioassays ranged from about $13: 1$ to $60: 1$, being lowest in the high salinity region and highest in the mid-estuary, either Stn E2 or E10. High ratios most likely reflect the importance of terrestrial and marsh organic matter inputs to the Parker River and the upper regions of the estuary and preferential remineralization of $\mathrm{N}$ relative to $\mathrm{C}$ (Hopkinson et al. 1997). The low ratios in the high salinity portion of the estuary likely reflect the input of phytoplankton or benthic algae to sediments.

There were large differences in initial inorganic nutrient concentrations, with dissolved inorganic nitrogen ranging between 2 and $135 \mu \mathrm{M}$ and inorganic $\mathrm{P}$ ranging between 0.1 and $10.7 \mu \mathrm{M}$ (Table 2). These concentrations are not typical for the estuarine water column and reflect the high magnitude of inorganic nutrient fluxes from sediments to the overlying water 
Table 2. Nutrient and dissolved organic matter concentrations and $\mathrm{C} / \mathrm{N}$ ratio of DOM at the outset of bacterial growth bioassays. Pre-contact DOC concentrations were measured prior to core incubations while post-contact concentrations were measured following core incubations just before bacterial growth incubations. Differences in DOC concentration less than $\sim 4 \%$ of pre-contact concentration (i.e. $~ 10$ to $30 \mu \mathrm{m}$ ) should not be considered significant. C/N ratios of DOM in the estuary typically range from about 10:1 to $14: 1$ (unpubl. data)

\begin{tabular}{|llcccrr|}
\hline Stn & Date & $\begin{array}{c}\text { DOC }(\mu \mathrm{M}) \\
\text { pre-contact }\end{array}$ & $\begin{array}{c}\text { DOC }(\mu \mathrm{M}) \\
\text { post-contact }\end{array}$ & $\begin{array}{c}\mathrm{C} / \mathrm{N} \\
\text { of DOM }\end{array}$ & $\begin{array}{r}\text { DIN } \\
(\mu \mathrm{M})\end{array}$ & $\begin{array}{r}\text { DIP } \\
(\mu \mathrm{M})\end{array}$ \\
\hline PRo & June & 611 & 695 & 25 & 31.5 & 1.1 \\
& December & 718 & 709 & 31 & 11.9 & 0.1 \\
E2 & June & 677 & 734 & 47 & 54.6 & 1.6 \\
& December & 792 & 758 & 58 & 28.2 & 0.2 \\
E10 & June & 490 & 542 & 60 & 135.3 & 7.1 \\
& December & 663 & 574 & 33 & 56.4 & 1.4 \\
E18 & June & 251 & 324 & 13 & 15.1 & 10.7 \\
& December & 409 & 403 & 25 & 2.5 & 0.3 \\
\end{tabular}

the estuarine water column bioassays, planktonic bacterial production was enhanced 1.5- to 3.4-fold following exposure to benthic sediments. The only previous reports of growth rates this high in Plum Island Sound were for experiments in which filtered water had received a substantial organic matter amendment made from leachates of live, green marsh macrophytes (Table 3, column 2, bottom entry; Hullar et al. 1996).

Growth rates of planktonic bacteria in Plum Island Sound (Wright et al. 1987) determined at field temperatures (Table 3, column 3) are generally much lower than we observed for the benthic bioassay bacteria and ranged from about 0.1 to $2.2 \mathrm{~d}^{-1}$. Even in more in association with organic matter decomposition and nutrient remineralization in sediments. This was especially true for nitrogen that was comprised almost exclusively of ammonium.

\section{Bacterial growth}

Numbers of bacteria increased exponentially for up to about $2 \mathrm{~d}$ from $<10^{4} \mathrm{ml}^{-1}$ to $2-10 \times 10^{6} \mathrm{ml}^{-1}$ (Fig. 1). Following an initial period of exponential growth, numbers either continued to increase slowly for the next several days or they oscillated at elevated levels. Presumably bacterial numbers did not continue to increase exponentially due to substrate limitation and the growth and activity of grazers that were added at low densities along with the bacterial inoculum. When counting bacteria, heterotrophic nanoflagellates began to be observed in low numbers after the first couple of days. Bioassays to which $\mathrm{HgCl}_{2}$ was added experienced no increase in bacterial numbers during the entire period.

Growth rates during the exponential phase were high, ranging from about 3.6 to almost $6.5 \mathrm{~d}^{-1}$ (Fig. 2). In general, growth rates were higher at each station in June than in December. Growth rates were also generally higher at the head of the estuary than they were closer to the ocean. For instance, in June growth rates decreased from about 6.5 to about $4.7 \mathrm{~d}^{-1}$ between PRO and E18 and in December they decreased from about 5 to about $3.7 \mathrm{~d}^{-1}$ between PRO and E18. These growth rates are substantially higher than those measured in bioassays using estuarine water not exposed to sediments (Table 3: column 2 shows room temperature bioassays while column 3 shows bioassays at field temperatures ranging from 5 to $28^{\circ} \mathrm{C}$ ). In comparison to productive and warmer southern salt marsh estuaries, planktonic bacterial growth rates are generally much lower (Newell et al. 1987, Riemann et al. 1987). Comparison with other studies is difficult, however, because different techniques have been employed and they were conducted under a range of temperatures.
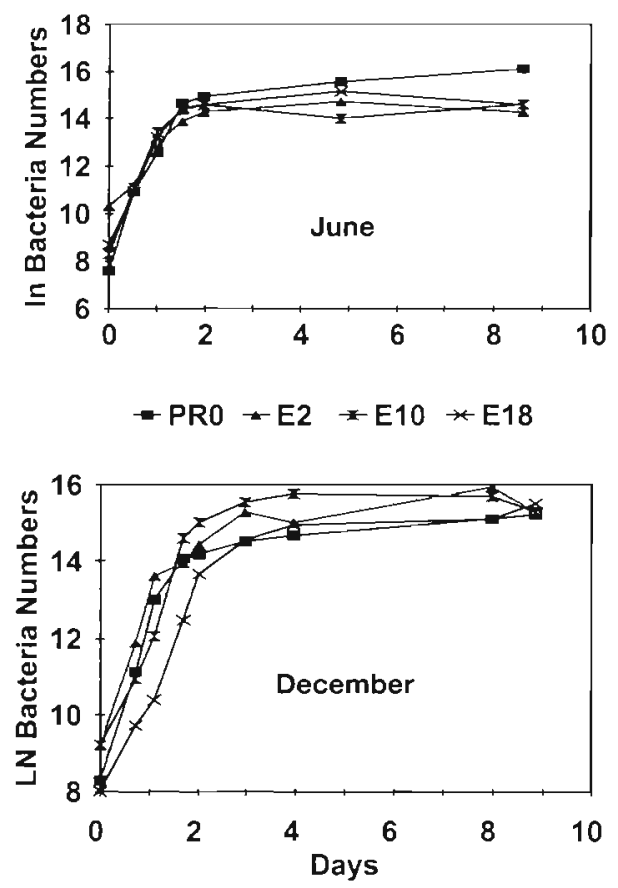

Fig. 1. Time course of number of bacteria (natural log transformed) in water previously held in close contact with estuarine and riverine sediments. Water had been filter sterilized and then inoculated with a $0.6 \mu \mathrm{m}$ filtrate of estuarine water containing a suite of microbial organisms, primarily bacteria. Results show average numbers calculated from 2 replicate bottles incubated under identical conditions. There was no growth in $\mathrm{HgCl}_{2}$ killed controls 


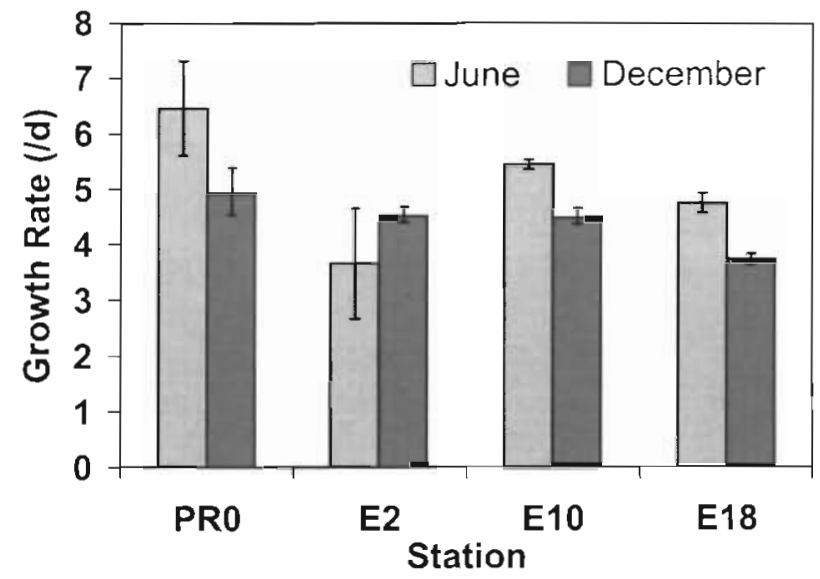

Fig. 2. Specific growth rates of bacteria in bioassays during their exponential growth phase. Error bars represent the standard error of the mean

For instance, in the above-mentioned studies, bacterial growth was based on an initially average standing stock of bacterioplankton, and measured by either increase in cell numbers after grazers were reduced (Wright \& Coffin 1983-0.7 $\mu$ filtration) or by radioisotope uptake (Newell et al. 1987, Riemann et al. 1987).

While the magnitude of bacterial production we observed is higher than in most reports for similar systems, the spatial and temporal patterns of production are similar. In the Plum Island Sound estuary, activity is highest in the summer and activity increases with distance up the estuary (Wright \& Coffin 1983, Wright et al. 1987). Similarly, Newell et al. (1987) reported higher levels of bacterial production in the upper Duplin River estuary than in the lower estuary. The

Table 3. Representative ranges of planktonic bacterial growth rates $\left(d^{-1}\right)$ in the Plum Island Sound estuary compared to growth rates following contact with the benthos or following the addition of macrophyte leachates. One of 2 methods was used to measure production: (1) increase in numbers following a $0.6 \mu \mathrm{m}$ inoculum addition to $0.2 \mu \mathrm{m}$ filtered water at room temperature and (2) increase in numbers following $0.7 \mu \mathrm{m}$ filtration alone and incubation at field temperatures ranging from 5 to $28^{\circ} \mathrm{C}$. The former method was used in this study. Results from the latter method have been reported previously (Wright et al. 1987). Effect of marsh macrophyte leachate amendments on planktonic bacterial production was measured at room temperature (Hullar et al. 1996)

\begin{tabular}{|c|c|c|c|}
\hline \multirow[t]{2}{*}{ Stn } & \multicolumn{2}{|c|}{ Planktonic growth rate $\left(\mathrm{d}^{-1}\right)$} & \multirow{2}{*}{$\begin{array}{c}\text { This study } \\
0.2 \mu \mathrm{m} \text { bioassay }\end{array}$} \\
\hline & $.2 \mu \mathrm{m}$ bioassay ${ }^{a}$ & $0.7 \mu \mathrm{m}$ bioassay ${ }^{b}$ & \\
\hline Upper estuary (E2) & $1.9-2.1$ & $0.1-0.7$ & $3.6-6.5$ \\
\hline Mid estuary (E10) & 1.9 & $0.2-2.1$ & $4.3-5.4$ \\
\hline Sound (E18) & $2.2-2.5$ & $0.2-2.2$ & $3.7-4.7$ \\
\hline Macrophyte leachate & $3.9-8.1$ & Not applicable & Not applicable \\
\hline
\end{tabular}

explanation for these patterns is that substrate inputs from marshes adjacent to the tidal creeks are highest in the headwater portions of the estuary (ratio of marsh area to water area is highest) and during summer (Wright et al. 1987). We extend this explanation and suggest that stimulatory effects of sediments are also highest in estuarine headwaters.

We suggest that the high specific growth rates of bacteria observed in this study are attributable to close contact of the incubation water with benthic sediments; presumably some substance(s) originating in the benthos stimulated bacterial growth. As mentioned above, estuarine bacterioplankton production in Plum sland Sound was enhanced substantially following addition of macrophyte leachates (Hullar et al. 1996). Prous attempts to determine controls of bacterial wh rates have focused on a combination of temperature, inorganic nutrients and organic matter supply or availability. For example, in a freshwater system, was enhanced by inorganic P additions. Shiah \& Ducklow (1994) and Carlson \& Ducklow (1996) found that controls differed regionally. In Chesapeake Bay, temperature appeared to be the major factor controlling bacterial growth rate. On the other hand, in the oligotrophic Sargasso Sea, enrichment experiments demonstrated that bacterial growth was primarily limited by available carbon. Research in high latitude systems has demonstrated that temperature and substrate supply affect bacteria interactively (Pomeroy et al. 1991, Viebe et al. 1992, Kirchman et al. 1993).

Of the potential factors contributing to elevated owth rates and differences in rates between stations and dates, temperature was not important in our study. All experiments were conducted at room temperature, well below temperatures observed in the field during summer. Inorganic nitrogen concentrations were substantially higher in 7 out of 8 bioassays than in the field and presumably could have stimulated specific growth rates of bacteria (Toolan et al. 1991). However, the spatial pattern of inorganic nitrogen elevation was different from that of growth rate. For example, the E10 bioassay had the most elevated $\mathrm{NH}_{4}{ }^{+}$concentration (on an absolute and relative basis), while highest growth rates were observed further up the estuary and river, at PRO and E2. Inorganic phosphorus was probably unimportant as well. In June $\mathrm{PO}_{4}^{3-}$ concentrations in the bioassays were lower than in ambient water at Stns PRO and E2 and higher than at E10 
and E18. Thus, temperature and inorganic nutrients were not likely to have been major factors contributing to the high specific growth rates of bacteria observed in the bioassays.

The most likely explanation for enhanced bacterial growth rates is that organic substrate supply was elevated in the bioassays as a result of prior sediment contact. However, an enhancement of supply is not readily demonstrated. On the basis of the direction of net fluxes of DOC between the sediments and water, we would expect different growth rate patterns than we observed. DOC concentrations in the June bioassay were all elevated relative to ambient estuarine water while in December concentrations were lower. While specific growth rates were higher in June than in December, rates in December were still quite high relative to those observed in the benthic-free bioassays (Table 3). Thus even though organic substrate levels were lower in the benthic bioassay than in the field, growth rates were higher.

In benthic flux determinations, only net fluxes of bulk constituents are measured, when in reality there may be substantially higher gross fluxes in both directions. There may be large fluxes of porewater constituents into the water column that are nearly balanced by fluxes of overlying water constituents in the opposite direction. There may be substantial differences in the chemical composition of DOC fluxing in the 2 directions. In anaerobic sediments, microbial $\mathrm{N}$ demands are low relative to $C$ needs due to the thermodynamic inefficiency of terminal electron acceptors utilized at low redox potentials (Thauer et al, 1977). Thus DOC/DON ratios of material fluxing from sediments may be higher than for material aerobically degraded in the water column. Indeed, DOC/DON ratios in water overlying cores invariably changed and usually were elevated following benthic incubations (see Table 2).

If bacterial growth rate is organic substrate limited and stimulated by sediment-derived DOC, we would expect to find a relation between growth rate and DOC concentration. We found a strong linear relation between DOC concentration at the beginning of the bacterial growth bioassays and the specific growth rates of bacteria during their exponential growth phase (Fig. 3). The higher the concentration, the higher the growth rate. Interestingly the relation between concentration and growth rate was different in June and December. For approximately the same DOC concentration, growth rates were about $1.5 \mathrm{~d}^{-1}$ higher in June than in December

These results suggest that growth rates of planktonic bacteria in this system may be organic substrate limited at all times. Wright \& Coffin (1984b) previously concluded that planktonic bacterial production in this

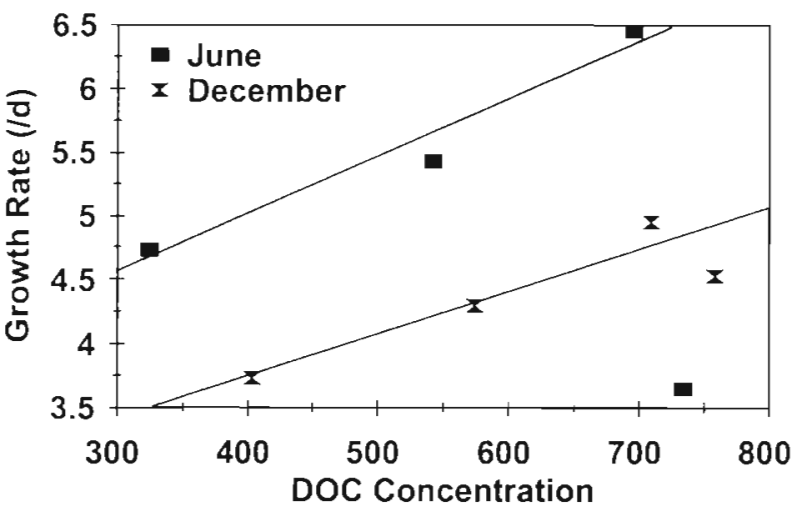

Fig. 3. Relationship between bacterial growth rates during exponential growth phase and initial concentrations of DOC $(\mu \mathrm{M})$ in bioassays. Line of best fit is plotted for June and December incubations (excluding Stn E2 from June). Intercepts of both lines are within $3 \mu \mathrm{M}$ of 0 . Slopes (significant at $p<0.05$ ) are 0.0028 and 0.0091 for December and June, respectively

system was primarily controlled by substrate supply. Our results further suggest that sediments are a source of labile organic matter that enhances bacterial growth rates above those normally found in the estuarine water column. Wainright (1987) reached similar conclusions. In sediment resuspension experiments in the laboratory, Wainright was able to demonstrate a $2.6 \times$ stimulation of bacterial production in seawater cultures containing resuspended organic matter. As a word of caution we note that our results cannot be extrapolated to field conditions. Our experiments were designed to assess the potential bioavailability of benthic-derived DOM, not to determine the relative importance of various limiting conditions on bacterial growth at specific times in the estuary. During winter, temperature could be a more important control of bacterial production than substrate supply.

\section{Sources of organic matter fueling bacterial production}

Stable isotopic compositions $\left(\delta^{13} \mathrm{C}\right.$ and $\left.\delta^{15} \mathrm{~N}\right)$ of microbes that grew and accumulated in the bioassay containers during the week long incubations ranged from -25.6 to $-10.2 \%$ for $\mathrm{C}$ and from -0.8 to $4.8 \%$ for $\mathrm{N}$ (Table 4). C isotopic ratios were similar in the Parker River and 2 upper estuary sites, ranging from only -25.6 to $-24 \%$. In contrast microbes that grew in the high salinity bioassay were quite heavy $(-10.2 \%)$. With $\mathrm{N}$, the 3 estuarine stations were similar $\left(\delta^{15} \mathrm{~N}\right.$ from -0.8 to $1.0 \%$ ) while the river station was substantially heavier $\left(\delta^{15} \mathrm{~N}: 4.8 \%\right.$ )

Stable isotopes may provide clues as to the source of organic matter fueling the microbial growth in the 
Table $4 . \delta^{13} \mathrm{C}$ and $\delta^{15} \mathrm{~N}$ values of major organic matter sources in estuarine ecosystems and of microbial-sized particles grown in water previously in close contact with riverine and estuarine sediments. Microbial-sized particles were sampled nonquantitatively from bioassay containers with a $0.7 \mu \mathrm{m}$ GF/F filter

\begin{tabular}{|lccc|}
\hline Source & $\delta^{13} \mathrm{C}$ range & $\delta^{15} \mathrm{~N}$ range & Source \\
\hline Terrestrial C $_{3}$ plants & -26 to -30 & -8 to 3 & $\mathrm{a}, \mathrm{b}$ \\
$\mathrm{C}_{3}$ freshwater marsh plants & -23 to -26 & 3.5 to 5.5 & $\mathrm{a}, \mathrm{d}$ \\
$\mathrm{C}_{4}$ saltwater marsh plants & -12 to -14 & 3 to 7 & $\mathrm{a}, \mathrm{c}$ \\
Benthic unicellular algae & -10 to -20 & 0 to 5 & $\mathrm{a}, \mathrm{c}$ \\
Marine phytoplankton & -18 to -24 & 6 to 9 & $\mathrm{a}_{1} \mathrm{c}$ \\
River-estuarine phytoplankton & -24 to -30 & 5 to 8 & a, e \\
Oligohaline POM - Plum Island Sound & -27.9 & 6 to 7 & $\mathrm{f}$ \\
Marine POM - Plum Island Sound & -21.9 & 6 to 7 & $\mathrm{f}$ \\
Benthic bacteria - freshwater (PR0) & -25.6 & 4.8 & This study \\
Benthic bacteria - low salinity (E2) & -24 & -0.8 & This study \\
Benthic bacteria - mid salinity (E10) & -24.3 & 1.0 & This study \\
Benthic bacteria - high salinity (E18) & -10.2 & 0.6 & This study \\
a, Fry \& Sherr (1984); b, Peterson \& Fry (1987); C, Currin et al. (1995); d, Sulli- \\
van \& Montcreiff (1990); e. Sigleo \& Macko (1985); f, Deegan \& Garritt (1997) \\
\hline
\end{tabular}

to phaeophytin always exceed 1 , indicating an actively growing population of benthic microalgae. Chl a standing stocks in sediments exceed those in the water column by a factor of 25 averaged over the year (176 vs $7 \mathrm{mg}$ chl a $\mathrm{m}^{-2}$ ). These observations indicate that the planktonic microbes that grew in the bioassays derived their organic substrate almost exclusively from benthic algae. The algae-derived DOC could have been produced directly from live or senescing algae or it could have been produced during the remineralization of algal detritus; our results do not differentiate these 2 routes, only that the DOC came from the sediments. These results indicate that there can be important gross fluxes of DOC from sediments to the

bioassays (Peterson \& Fry 1987). The organic matter at estuarine stations (E2, E10, E18) potentially comes from at least 6 major primary sources: fresh and marine phytoplankton, fresh and salt marsh vegetation, terrestrial plants and benthic unicellular algae (Table 4). The organic matter at Stn PR0 comes potentially from freshwater plankton, fresh marsh and submerged aquatic vegetation, terrestrial plants and unicellular benthic algae. As the number of potential sources exceeds the number of isotopes available for discriminating sources, it is impossible to unequivocally specify the mix of organic matter sources for any particular sample. However in conjunction with other information it is often possible to identify the most likely organic matter sources.

The data in Table 4 illustrates that with the exception of the E18 bacteria, all the bioassay bacteria fall between the $\delta^{13} \mathrm{C}$ and $\delta^{15} \mathrm{~N}$ values for at least 2 potential organic matter sources for the sites. The bacteria that accumulated in the Stn E18 bioassay (lower estuary) were enriched in ${ }^{13} \mathrm{C}\left(\delta^{13} \mathrm{C}:-10.2 \%\right.$ ) and depleted in ${ }^{15} \mathrm{~N}\left(\delta^{15} \mathrm{~N}: 0.6 \%\right)$. These ratios are distinctly different from particulate organic matter in the water column $\left(\delta^{13} \mathrm{C}:-21.9 \%, \delta^{15} \mathrm{~N}: 6\right.$ to $7 \%$ ), which resembles oceanic phytoplankton $\left(\delta^{13} \mathrm{C}:-22 \%, \delta^{15} \mathrm{~N}: 6\right.$ to $9 \%$, and all other potential sources other than benthic algae. The combination of $\delta^{13} \mathrm{C}$ and $\delta^{15} \mathrm{~N}$ ratios strongly suggests that the major source of organic matter fueling bacterial production at Stn E18 was benthic unicellular algae $\left(\delta^{13} \mathrm{C}:-10\right.$ to $-20 \%, \delta^{15} \mathrm{~N}: 0$ to $5 \%$ ).

Ancillary information from the site supports this conclusion (Hopkinson et al. in press). Chl a concentrations are high in the sandy sediments in the lower estuary with standing crops in the surface centimeter of sediment ranging from 25 to $253 \mathrm{mg} \mathrm{m}^{-2}$. Ratios of chl a overlying water that are not indicated by net flux measures as are made during benthic flux studies. The relatively low inorganic $\mathrm{N}$ concentrations in the sediments and bioassay water for this very sandy site suggest that inorganic $N$ uptake by bacteria probably does not influence the isotopic composition of bioassay microbes at this site.

Stable isotopic compositions of the bioassay microbes from Stns E2 and E10 (Table 4) are relatively light with respect to $N\left(\delta^{15} \mathrm{~N}:-0.8\right.$ to $\left.1.0 \%\right)$ and in the mid-range for $\mathrm{C}\left(\delta^{13} \mathrm{C}:-24.3\right.$ to $\left.-24 \%\right)$. On first examination it would appear that a mixture of benthic microalgae and terrestrial organic matter are the primary organic matter sources of the bioassay microbes (only sources with similar $\delta^{15} \mathrm{~N}$ ). However, the presumed relative importance of terrestrial inputs does not seem warranted. Terrestrial organic matter inputs are equivalent to only about $9 \%$ of total potential inputs, including that from phytoplankton, marsh macrophytes and epibenthic algae (Deegan \& Garritt 1997). It is likely that bioassay microbes immobilized considerable inorganic $\mathrm{N}$ while growing on the very $\mathrm{C}$ rich and $\mathrm{N}$ poor organic substrate $(\mathrm{C} / \mathrm{N}$ ratio of $\mathrm{DOM}$ between 33 and 60:1, Table 2; see Goldman \& Dennett 1991, Vallino et al. 1996). Ammonium concentrations were very high in the bioassays as a result of prior efflux from sediment porewaters (Tables $1 \& 2$ ). $\delta^{15} \mathrm{~N}$ of $\mathrm{NH}_{4}{ }^{+}$was not measured, but it is presumably relatively heavy as a result of sediment nitrification and denitrification (Cline \& Kaplan 1975). As isotopic fractionation is typically large when substrate is abundant, bacteria are apt to be 5 to $15 \%$ lighter than the substrate (Peterson \& Fry 1987). Thus the relatively light $\delta^{1.5} \mathrm{~N}$ of the bioassay microbes probably reflects uptake of inorganic $\mathrm{N}$ as opposed to organic $\mathrm{N}$. Consequently the 
value of $\delta^{15} \mathrm{~N}$ in tracing organic matter sources is lost. Unfortunately, $\delta^{13} \mathrm{C}$ alone provides little help in identifying the several potential organic matter sources because the $\delta^{13} \mathrm{C}$ of the microbes is in the mid-range of a variety of possible source mixtures.

Bioassay microbes for the freshwater station (PRO) had a $\delta^{13} \mathrm{C}$ and $\delta^{15} \mathrm{~N}$ signature overlapping that for freshwater phytoplankton and fresh marsh macrophyctes. This distribution indicates that the microbes derive most of their organic matter from a mixture of these 2 sources. However, due to the central location of the microbes on both $\delta^{13} \mathrm{C}$ and $\delta^{15} \mathrm{~N}$ axes, it is also possible that terrestrial and benthic microalgae comprise an important source of organic matter. Other information supports this conclusion. $\mathrm{Chl}$ a levels at the station are typically high in both sediments (19 to $44 \mathrm{mg} \mathrm{m}^{-2}$ ) and the water column (10 to $60 \mathrm{mg} \mathrm{m}^{-2}$ ). Sediment organic content is higher at this station than at any of the estuarine sites (Table 1). Much of the organic matter undoubtedly represents particulate organic matter carried in from the watershed and deposited in the quiet waters of the reservoir behind the dam.

\section{CONCLUSIONS}

Planktonic bacteria grew very rapidly in water previously in close contact with estuarine sediments. Specific bacterial growth rates were several-fold greater than rates determined in water column bioassays or in this estuary under field conditions as well as estuaries in general. It appears that growth rates were elevated as a result of dissolved organic matter exchange with bottom sediments. While net exchanges of DOC across the sediment-water interface were low or even into the sediments, planktonic microbes incorporated an isotopic signature of organic matter produced within sediments. These results suggest that there were gross fluxes of organic matter across the sediment-water interface that were not apparent from net changes in DOC concentration in the overlying water pool. There was also indication that planktonic bacteria were supplementing their organic matter diet, which is deficient in $\mathrm{N}$ as indicated by $\mathrm{C} / \mathrm{N}$ ratios up to $60: 1$, with inorganic $N$ remineralized in the sediments and exchanged with the overlying water. This study indicates that benthic systems must not only be seen as sites of inorganic nutrient remineralization important in support of planktonic primary producers, but also as sites of dissolved organic matter generation important in support of bacterioplankton production.

Acknowledgements. This work was supported by grants from the National Science Foundation (OCE-9214461 and OCE9726921), the Woods Hole Oceanographic Sea Grant pro- gram, and the Sweetwater Foundation. Discussions on earlier drafts of this manuscript with Hugh Ducklow, Tony Michaels, Barry Sherr and Joe Vallino were helpful in improving the manuscript.

\section{LITERATURE CITED}

Ammerman J, Fuhrman J, Hagström $\AA$, Azam F (1984) Bacterioplankton growth in seawater: 1. Growth kinetics and cellular characteristics in seawater cultures. Mar Ecol Prog Ser 18:31-39

Boynton W, Kemp W, Osborne C (1980) Nutrient fluxes across the sediment-water interface in the turbid zone of a coastal plain estuary. In: Kennedy $V$ (ed) Estuarine perspectives. Academic Press, New York, p 93-110

Burdige DJ, Alperin M, Homstead J, Martens C (1992) The role of benthic fluxes of dissolved organic carbon in oceanic and sedimentary carbon cycling. Geophys Res Lett 19:1851-1854

Burdige DJ, Homstead J (1994) Fluxes of dissolved organic carbon from Chesapeake Bay sediments. Geochim Cosmochim Acta 58:3407-3424

Carlson C, Ducklow H (1996) Growth of bacterioplankton and consumption of dissolved organic carbon in the Sargasso Sea. Aquat Microb Ecol 10:69-85

Cline J, Kaplan I (1975) Isotopic fractionation of dissolved nitrate during denitrification in the eastern tropical north Pacific Ocean. Mar Chem 3:271-299

Currin CA, Newell S, Paerl $H$ (1995) The role of standing dead Spartina alterniflora and benthic microalgae in salt marsh food webs: considerations based on multiple stable isotope analysis. Mar Ecol Prog Ser 121:99-116

Deegan LA, Garritt RH (1997) Evidence for spatial variability in estuarine food webs. Mar Ecol Prog Ser 147:31-47

Emerson S, Dymond J (1984) Benthic organic carbon cycles: toward a balance of fluxes from particles settling and pore water gradients. In: Global Ocean Flux Study: Proc Workshop. Natl Acad Press

Fry B, Hullar M, Peterson B, Saupe S, Wright R (1991) DOC production in a salt marsh estuary. Arch Hydrobiol Beih $37: 1-8$

Fry B, Sherr E (1984) $\delta^{13} \mathrm{C}$ measurements as indicators of carbon flow in marine and freshwater ecosystems. Contrib Mar Sci 27:13-47

Giblin AE, Hopkinson CS. Tucker J (1997) Benthic metabolism and nutrient cycling in Boston Harbor, Massachusetts. Estuaries 20:344-362

Goldman J, Dennett M (1991) Ammonium regeneration and carbon utilization by marine bacteria grown on mixed substrates. Mar Biol 109:369-378

Grasshoff K, Ehrhardt M, Kremling K (1983) Methods of seawater analysis. Verlag Chemie, Basel

Hartwig EO (1976) Nutrient cycling between the water column and a marine sediment. I. Organic carbon. Mar Biol $34: 285-295$

Hopkinson CS (1987) Nutrient regeneration in shallow-water sediments of the estuarine plume region of the nearshore Georgia Bight, USA. Mar Biol 94:127-142

Hopkinson CS, Fry B, Nolin A (1997) Stoichiometry of dissolved organic matter dynamics on the continental shelf of the Northeastern United States. Cont Shelf Res 17:473-489

Hopkinson CS, Giblin AE, Tucker J, Garritt H (in press) Benthic metabolism and nutrient cycling along an estuarine salinity gradient. Estuaries

Hullar M, Fry B, Peterson B, Wright R (1996) Microbial utilization of estuarine dissolved organic carbon: a stable 
isotope tracer approach tested by mass balance. Appl Environ Microb 62:2489-2493

Kirchman D, Keil R, Simon M, Welschmeyer N (1993) Biomass and production of heterotrophic bacterioplankton in the oceanic subarctic Pacific. Deep-Sea Res 40:967-988

Kirchman D, Suzuki Y, Garside C, Ducklow H (1991) High turnover rates of dissolved organic carbon during a spring phytoplankton bloom. Nature 32:612-614

Martin WR, McCorkle D (1994) Dissolved organic carbon concentrations in marine pore waters determined by high temperature oxidation. Limnol Oceanogr 38:1464-1479

Newell S, Fallon R, Sherr B, Sherr E (1987) Mesoscale temporal variation in bacterial standing crop, percent active cells, productivity and output in a saltmarsh tidal river. Proc S I L Congr 23:1839-1845

Nixon SW (1981) Remineralization and nutrient cycling in coastal marine ecosystems. In: Neilson $B_{1}$ Cronin $L$ (eds) Estuaries and nutrients. Humana Press, Clifton, NJ, p $111-138$

Nixon SW, Kelly J, Furnas B, Oviatt C, Hale S (1980) Phosphorus regeneration and the metabolism of coastal marine bottom communities. In: Tenore $K$, Coull B (eds) Marine benthic dynamics. University of South Carolina Press, Columbia, p 219-242

Peterson B, Fry B (1987) Stable isotopes in ecosystem studies. Annu Rev Ecol Syst 18:293-320

Peterson BJ, Fry B, Hullar M, Saupe S, Wright R (1994) The distribution and stable carbon isotopic composition of dissolved organic carbon in estuaries. Estuaries 17:111-121

Pomeroy L, Wiebe W, Deibel D, Thompson R, Rowe G, Pakulski D (1991) Bacterial responses to temperature and substrate concentration during the Newfoundland and spring bloom. Mar Ecol Prog Ser 75:143-159

Porter K, Feig Y (1980) The use of DAPI for identifying and counting aquatic microflora. Limnol Oceanogr 25:943-948

Riemann B, Bjornsen P, Newell S, Fallon R (1987) Calculation of cell production of coastal marine bacteria based on measured incorporation of thymidine. Limnol Oceanogr $32: 471-476$

Shiah R, Ducklow H (1994) Temperature and substrate regulation of bacterial abundance, production and specific growth rate in Chesapeake Bay, USA. Mar Ecol Prog Ser 103:297-308

Sigleo A, Macko S (1985) Stable isotope and amino acid composition of estuarine dissolved colloidal material. In Sigleo A, Hattori A (eds) Marine and estuarine geochemistry. Lewis Publishers, Inc, Chelsea, MI, p 29-46

Smith SV. Hollibaugh T (1993) Coastal metabolism and the oceanic organic carbon balance. Rev Geophys 31:75-89

Editorial responsibility: Robert Sanders

PhiladeIphia, Pennsylvania, USA
Sullivan M, Montcreiff C (1990) Edaphic algae are an important component of salt marsh foodwebs: evidence from multiple stable isotope analyses. Mar Ecol Prog Ser 62 : 149-159

Thauer RK, Jungermann K, Decker K (1977) Energy conservation in chemotrophic anaerobic bacteria. Bacteriol Rev $41: 100-180$

Toolan T, Wehr J, Findlay S (1991) Inorganic phosphorus stimulation of bacterioplankton production in a mesoeutrophic lake. Appl Environ Microbiol 57:2074-2078

Vallino J, Hopkinson C, Hobbie J (1996) Modeling bacterial utilization of dissolved organic matter: optimization replaces Monod growth kinetics. Limnol Oceanogr 41 : $1591-1609$

Verity P. Sieracki M (1993) Use of color image analysis and epifluorescence microscopy to measure plankton biomass. In: Kemp P, Sherr B, Sherr E, Cole J (eds) Handbook of methods in aquatic microbial ecology. Lewis Publishers, Ann Arbor, MI, p 327-338

Vörösmarty C, Loder I (1994) Spring-neap tidal contrasts and nutrient dynamics in a marsh-dominated estuary. Estuaries 17:537-551

Wainright SC (1987) Stimulation of heterotrophic microplankton production by resuspended marine sediments. Science 238:1710-1712

Wiebe W, Sheldon W, Pomeroy L (1992) Bacterial growth in the cold: evidence for an enhanced substrate requirement. Appl Environ Microbiol 58:359-364

Williams PM, Druffel E (1987) Radiocarbon in dissolved organic matter in the central North Pacific Ocean. Nature 330:246-248

Wright RT, Coffin R (1983) Planktonic bacteria in estuaries and coastal waters of northern Massachusetts: spatial and temporal distribution. Mar Ecol Prog Ser 11:205-216

Wright RT, Coffin R (1984a) Measuring microzooplankton grazing on planktonic marine bacteria by its impact on bacterial production. Microb Ecol 10:137-149

Wright RT, Coffin R (1984b) Factors affecting bacterioplank ton density and productivity in salt marsh estuaries In: Klug M, Reddy C (eds) Current perspectives in microbial ecology. Am Soc Microbiology, Washington, DC, p $485-494$

Wright RT, Coffin R, Lebo M (1987) Dynamics of planktonic bacteria and heterotrophic microflagellates in the Parker Estuary, northern Massachusetts. Cont Shelf Res 7 : $1383-1397$

Zweifel UL, Norrman B, Hagström \& (1993) Consumption of dissolved organic carbon by marine bacteria and demand for inorganic nutrients. Mar Ecol Prog Ser 101:23-32

Submitted: June 25, 1997; Accopted: June 17, 1998 Proofs received from author(s): November 11, 1998 